\title{
Review Article: Does kombucha tea attenuate the hepato-nepherotoxicity induced by a certain environmental pollutant?
}

\author{
Ola Ali Gharib \\ Drug Radiation Research Department, National Center for Radiation Research and \\ Technology, Atomic Energy Authority.
}

\begin{abstract}
Trichloroethylene (TCE) may induce oxidative stress which generates free radicals and alters antioxidants or oxygen-free radical scavenging enzymes. The aim of this study was to investigate the protective role of oral administration of kombucha tea in rats with TCE as an environmental pollutant. Methods: Twenty male albino rats were divided into four groups: the control group treated with vehicle, Kombucha (KT)-treated group, TCE-treated group and KT/TCE-treated group. Liver and kidney lipid peroxidation, glutathione content, nitric oxide (NO) and total blood free radical concentrations were evaluated. Serum urea, creatinine level, gamma-glutamyl transferase (GGTP) and lactate dehydrogenase (LDH) activities were also measured.

Results: TCE administration increased the malondialhyde (MDA) and NO contents in liver and kidney, urea and creatinine concentrations in serum, total free radical level in blood and GGTP and LDH activities in serum, whereas it decreased the glutathione (GSH) level in liver and kidney homogenate. KT administration significantly improved lipid peroxidation and oxidative stress induced by TCE. Conclusion: The present study indicates that Kombucha may repair damage caused by environmental pollutants such as TCE and may be beneficial to people who deal with these chemicals.
\end{abstract}

Key word: kombucha, hepato-nephrotoxicity, TCE.

\section{INTRODUCTION}

Kombucha is a sour beverage prepared from the fermentation of black tea and sugar with a symbiotic culture of acetic acid bacteria and yeasts such as Bacterium xylinum, Bacterium xylinoides, Bacterium gluconicum, Saccharomyces ludwigii, Saccharomyces apiculatus varieties, Schizosaccaromycespombe, Acetobacter ketogenum, Torula varieties, Pichia fermantans and other yeasts reported to have potential health effects, Morales, G.B. and Sanchez H.H. (2003). Fermentation and oxidation processes of Kombucha microorganisms produce a wide range of organic acids, vitamins and enzymes. Research indicated that Kombucha improved resistance against cancer, prevented cardiovascular diseases, promoted digestion, stimulated immunity and reduced inflammation Dufresne, C. and Farnworth, E. (2000). Glucuronic acid is one of the organic acids produced during fermentation process in Kombucha and may improve oxidative metabolism, Blanc, P. J. (1996). Trichloroethylene (TCE) is a major environmental contaminant and an occupational concern due to its widespread industrial use, Davidson, I. W. and Belilies, R.P. (1991). An animal carcinogen, TCE is nephrotoxic as well as hepatotoxic and causes both hepatic and renal tumors in rats, Maltoni, C. et al. (1988). The toxicity of TCE depend on its reactive metabolites derived from the reaction of either glutathione conjugating nor P450 with TCE, the reaction of 
glutathione conjugating with TCE followed by subsequent metabolism by gammaglutamyl transferase (GGTP), dipeptidases and cystein conjugate B-layse, Geoptar, A.R. et al.(1995). The present study aims to investigate the antioxidant properties of Kombucha constituents and the protective effects of Kombucha on the liver and kidney of TCE-treated rats.

\section{MATERIAL AND METHODS}

Animals

Twenty male albino rats weighing 150-200 g were purchased from the Egyptian Organization for Biological Products and Vaccines (Cairo, Egypt). Animals were housed in cages with good ventilation and illumination and provided with standard diet and water ad-libitum. All procedures in the present study conform to international animal care guidelines and the ethics committee of the institution.

\section{Chemicals}

Analytical-grade TCE was purchased from El-Nasr Pharmaceutical Chemical (Egypt). All other chemicals and bio-chemicals were obtained from Sigma Chemical (USA). The kits used in the experiments were purchased from Bio-Diagnostics (UK).

\section{Preparation of Kombucha}

One hundred grams (100 g) of sugar was added to one liter $(1 \mathrm{~L})$ of distilled water, and the solution was boiled for 15 minutes in a sterile conical flask. Six tea bags of black tea powder (Lipton, Egypt) were added to the flask (12 g/L, 1.2\%) and allowed to cool to room temperature for one hour.

\section{Fermentation}

Kombucha culture was kept under aseptic conditions. Fermentation was carried out by incubating the Kombucha culture at $28 \pm 1{ }^{\circ} \mathrm{C}$ for $8-10$ days. Subsequently, the medium (brew) was centrifuged at $3000 \mathrm{rpm}$ for 30 minutes aseptically and stored in polypropylene vials at $-20^{\circ} \mathrm{C}$ for further use, Sai Ram M. et al. (2000).

Study design

Rats were divided into four groups (5 rats per group), namely the control group, Kombucha (KT) group, TCE group and KT/TCE group. In the control group, animals $(n=5)$ were gavage fed with maize oil (vehicle of TCE) for ten consecutive days. In the KT group, animals $(n=5)$ were administered with KT ferment per oral (0.1 ml per $100 \mathrm{~g}$ of body weight) for two weeks, Gharib, O. A. and Fahim, T. H. (2007). In the TCE group, animals $(n=5)$ were administrated with TCE $(1 \mathrm{~g}$ per $\mathrm{kg}$ of body weight) per oral for ten consecutive days, Elcombe, C.R.; et al. (1985). In the KT/TCE group, animals $(n=5)$ were administered with KT ferment first for two weeks and subsequently gavage fed with TCE for ten consecutive days. Animals were sacrificed 24 hours after TCE administration. Liver and kidneys were removed. Serum was isolated for the assessment of liver and kidney functions.

\section{Total free radicals assay by electron spin resonanc etechnique (ESR)}

Electron spin resonance occurs when a spinning electron in an externally applied magnetic field absorbs sufficient electromagnetic radiation to cause inversion of electrons spin state (e.g. transfer from ground state to excited state). This technique is used to study free radical concentrations in biological materials by detecting the molecules with unpaired electrons (free radicals) without destroying them. Free radicals from biological materials such as reactive oxygen species (O2-), hydroxyl radical ( $\mathrm{OH}-)$, nitrogen oxide (NO-) and hypochlorous acid (HOCL-) are responsible for certain diseases, Heckly, R. J. (1975). 


\section{Preparation of lyophilized blood samples for ESR}

Blood samples were lypophilized in a super Modulyo freeze dryer (Edwards Vacuum, UK).

\section{ESR spectrometer}

ESR or electron paramagnetic resonance (EPR) signals were recorded at room temperature by a Bruker EMX spectrometer (X band, Bruker, Germany). ESR detection limits (1013 spins/g) depend on the sample type, sample size, detector sensitivity, frequency of incident radiation and electronic circuit of the instrument

\section{Measurement and analysis of ESR spectra}

Samples were inserted into the EPR of quartz tubes and measured at suitable instrument parameters. The peak height of the radiation-induced EPR signals was determined for each sample. The reading intensities were divided by the weight of each sample for normalization. To monitor variation in the peak height EPR signals as a function of magnetic field, we measured intensities as the distance between top and bottom points of the first derivative and the reading intensities were divided by sample weight of each sample for the calculation of normalization values which were recorded according to Gohn, A. (1986). \& Pascual, E.C. et al. (2002).

\section{Biochemical assays}

All biochemical assays were performed with a Helios Thermo-Spectronic spectrophotometer (Thermo Spectronic, UK). Lactate dehydrogenase (LDH) activity was evaluated according to the method by IFCC, (1980). GGTP activity was evaluated according to the method by Szasz, G. (1969). Urea concentration was measured according to the method by, Halled, C. J. \& Cook, J. G. (1971)., with a Bio-Diagnostic kit. Creatinine level was measured according to the method by, Henery, R. J. (1974)., with a Bio-Diagnostic kit. Total protein of serum and kidney was measured according to the method by, Gomal, A. C. et al. (1949). Concentration of both liver and kidney malondialdehyde (MDA) was analyzed according to the method by, Yoshioka, T. et al. (1979). Liver and kidney homogenate of GSH content was measured according to the method by, Beutler, E. et al. (1963). Nitric oxide (NO) concentration was measured according to the method by, Geng, Y. et al. (1994).

\section{Statistical analysis}

Quantitative data were expressed as mean \pm SD (standard deviation) and analyzed by one way analysis of variances (ANOVA) followed by Tukey's multiple comparison test. Statistical analysis was performed with the Graph Pad software (USA). Differences were considered statistically significant when $P<0.05$.

\section{RESULTS}

In the present study, hepato-renal protection effects of KT were investigated through liver and kidney functions affected by carcinogen, e.g. serum urea, creatinine concentration, LDH and GGTP activity.

\section{TCE administration}

TCE administration significantly increased urea by $103.05 \%(P<0.001)$ and creatinine by $28.70 \%(P<0.01)$ levels in rats (Table 1$)$. Administration of TCE induced a marked oxidative stress measured by significant increase lipid peroxidation $78.37 \% \& 64.07 \%(P<0.001)$ and significant inhibition in GSH content by $-29.33 \%$ \&$26.89 \%(P<0.01)$. Serum LDH activity by $45.97 \%(P<0.001)$, as well as liver and kidney NO concentration $61.55 \% \& 97.57 \%(P<0.001)$ were significantly increased (Table 1,2). TCE administration significantly increased total free radicals in blood by $582.97 \%(P<0.001)$ and in serum GGTP activity by $38.86 \%(P<0.01)$ (Table 2$)$. 
Table 1: Effect of KT ferment and/ or TCE administration on serum urea (mmol/l), creatinine, $(\mathrm{mg} / \mathrm{dl})$ concentration and LDH activity (U/L), as well as kidney homogenate of MDA ( $\mu \mathrm{mol} / \mathrm{g}$ protein), GSH content (mg/g protein) and NO concentration $(\mu \mathrm{mol} / \mathrm{g}$ protein) of male rats estimated twenty- four hours after last treatment.

\begin{tabular}{|c|c|c|c|c|}
\hline & Control & $\begin{array}{c}\mathrm{Kt} \\
\text { Administration }\end{array}$ & TCE administration & $\begin{array}{c}\mathrm{Kt} / \mathrm{TCE} \\
\text { Administration }\end{array}$ \\
\hline Serum Urea & & & & \\
\hline $\begin{array}{c}\text { Concentration } \\
\mathrm{mmol} / \mathrm{l}\end{array}$ & $3.635 \pm 0.388$ & $3.896 \pm 0.34$ & $7.381 \pm 0.881^{(\mathrm{a}, \mathrm{b})}$ & $5.794 \pm 1.492^{(\mathrm{a}, \mathrm{b}, \mathrm{c})}$ \\
\hline $\begin{array}{c}\text { Serum Creatinine } \\
\text { concentration }(\mathrm{mg} / \mathrm{dl})\end{array}$ & $0.864 \pm 0.0921$ & $0.824 \pm 0.1315$ & $1.112 \pm 0.0867^{(\mathrm{a}, \mathrm{b})}$ & $0.952 \pm 0.0335$ \\
\hline $\begin{array}{c}\text { Serum } \mathrm{LDH} \text { activity } \\
(\mathrm{U} / \mathrm{L})\end{array}$ & $377.6 \pm 39.72$ & $366.2 \pm 44.65$ & $551.2 \pm 68.89^{(\mathrm{a}, \mathrm{b})}$ & $395.6 \pm 32.19^{(\mathrm{c})}$ \\
\hline $\begin{array}{c}\text { Kidney MDA } \\
\text { concentration } \\
(\mu \mathrm{mol} / \mathrm{g} \text { protein })\end{array}$ & $22.020 \pm 4.385$ & $21.800 \pm 2.142$ & $36.13 \pm 1.461^{(\mathrm{a}, \mathrm{b})}$ & $27.300 \pm 3.179^{(\mathrm{b}, \mathrm{c})}$ \\
\hline $\begin{array}{l}\text { Kidney GSH content } \\
\text { (mg/ g protein) }\end{array}$ & $1.242 \pm 0.0471$ & $1.416 \pm 0.1711$ & $0.908 \pm 0.0814^{(\mathrm{a}, \mathrm{b})}$ & $1.229 \pm 0.1794^{(\mathrm{c})}$ \\
\hline $\begin{array}{c}\text { Kidney NO } \\
\text { concentration }(\mu \mathrm{mol} / \mathrm{g} \\
\text { protein })\end{array}$ & $19.78 \pm 1.808$ & $21.93 \pm 2.095$ & $39.08 \pm 6.562^{(a, b)}$ & $29.22 \pm 4.181^{(\mathrm{a})}$ \\
\hline
\end{tabular}

Table 2: Effect of KT ferment and/ or TCE administration on blood free radical concentration (radicals/g) $) \times 10^{7}$ and serum GGTP activity (U/L), as well as liver homogenate of MDA ( $\mu \mathrm{mol} / \mathrm{g}$ protein), GSH content (mg/g protein) and NO concentration ( $\mu$ mol/ g protein) of male rats estimated twenty- four hours after last treatment.

\begin{tabular}{|c|c|c|c|c|}
\hline & Control & $\begin{array}{c}\mathrm{Kt} \\
\text { Administration } \\
\end{array}$ & TCE administration & $\begin{array}{c}\mathrm{Kt} / \mathrm{TCE} \\
\text { Administration } \\
\end{array}$ \\
\hline $\begin{array}{c}\text { Blood total free radicals } \\
\text { Concentration } \\
(\text { Radicals } / \mathrm{g}) \times 10^{7}\end{array}$ & $0.329 \pm 0.032$ & $0.384 \pm 0.0233$ & $2.247 \pm 0.3629^{(\mathrm{a}, \mathrm{b})}$ & $0.801 \pm 0.102^{(\mathrm{a}, \mathrm{b}, \mathrm{c})}$ \\
\hline $\begin{array}{c}\text { Serum GGTP activity } \\
(\mathrm{u} / \mathrm{L})\end{array}$ & $2.182 \pm 0.331$ & $2.121 \pm 0.303^{(\mathrm{b})}$ & $3.030 \pm 0.429$ & $2.060 \pm 0.331^{(\mathrm{c})}$ \\
\hline $\begin{array}{l}\text { Liver MDA concentration } \\
\qquad(\mu \mathrm{mol} / \mathrm{g} \text { protein })\end{array}$ & $22.06 \pm 2.493$ & $13.71 \pm 0.123^{(\mathrm{a}, \mathrm{c})}$ & $39.35 \pm 5.852^{(\mathrm{a}, \mathrm{b})}$ & $22.87 \pm 3.598^{(\mathrm{b}, \mathrm{c})}$ \\
\hline $\begin{array}{c}\text { Liver GSH } \\
\text { content } \\
(\mathrm{mg} / \mathrm{g} \text { protein })\end{array}$ & $1.275 \pm 0.105$ & $1.637 \pm 0.177^{(\mathrm{a}, \mathrm{c})}$ & $0.901 \pm 0.074^{(\mathrm{a}, \mathrm{b})}$ & $1.068 \pm 0.089^{(b)}$ \\
\hline $\begin{array}{l}\text { Liver NO concentration } \\
\quad(\mu \mathrm{mol} / \mathrm{g} \text { protein })\end{array}$ & $20.29 \pm 0.868$ & $21.29 \pm 1.384^{(\mathrm{a}, \mathrm{c})}$ & $32.78 \pm 2.860^{(\mathrm{a}, \mathrm{b})}$ & $25.80 \pm 2.252^{(\mathrm{a}, \mathrm{b}, \mathrm{c})}$ \\
\hline
\end{tabular}

Data are presented as mean \pm SD. $(n=5)$. ${ }^{(a)}$ Significantly different from control group at $\mathrm{P}<0.05$. ${ }^{\text {(b) }}$ Significantly different from KT group at $\mathrm{P}<0.05$. ${ }^{\text {(c) }}$ Significantly different from TCE group at $\mathrm{P}<0.05$. KT $=$ kombucha tea fermented, TCE: trichloroethylene administered.

\section{Recovery}

Data of liver and kidney GSH, LDH and NO concentration (Table 1, 2) showed that KT administration restored these parameters to normal values in TCEtreated rats. Moreover, a significant improvement in serum creatinine as well as liver and kidney MDA was observed (Tables 1 and 2).

\section{DISCUSSION}

The present study confirms the findings of Goel et al. and Khan et al. that TCE significantly increased urea and creatinine in rats, Goel, S.K. et al. (1992) and Khan, S. et al. (2009)., and that TCE also increased the activity of LDH as reported by, Lash, L. H. et al. (2002). Moreover, oxidative markers measured as lipid peroxidation in liver and kidney tissue as well as total free radicals in blood increased markedly followed by a decrease in liver and kidney glutathione content. Previous studies found significant hepato-renal dysfunction in male Sprague Dawley rats exposed to TCE. 
The renal dysfunction was manifested by glycosuria and alterations in plasma creatine, urine nitrogen, uric acid and creatine clearance, concentration related changes in hematocrit and erythrocytes, as well as reticulocyte and erythroblast counts, Nomiyama, K. et al. (1986)., and Agency for Toxic Substances and Disease Registry (ATSDR) (1997)., while the hepatic dysfunction showed alteration in plasma AST, ALT, GGTP as well as liver MDA, GSH and NO concentration, Mohammed, M. A. (2008). TCE induced oxidative stress, Cojocel, C. et al. (1989)., which is considered an imbalance between the production of oxidizing molecular species (free radicals) and the presence of cellular antioxidants, Dalton, T.P. et al. (1999). Containing unpaired electron, free radicals are highly reactive and cause damage to part of cells by inducing DNA strand breaks, purine oxidation and protein DNA cross linking and cell membrane damage, Giordano, F.J. (2005). Accumulation of such damage may cause cell death, Halliwell, B. \& Whiteman, M. (2004)., and Wang, G. et al. (2007)., reported that TCE exposure not only increased lipid peroxidation but also accelerated autoimmune responses. Lash et al. documented that kidney cells from male rats are more sensitive to TCE than those from female rats or hepatocytes from rats of either sex, Lash, L.H. et al. (2001). Moreover, acute renal cellular injury from TCE is believed to be associated with metabolites derived from the GSH conjugation pathway Geoptar, A.R. et al. (1995). The first step involve conjugation with GSH that catalyze by the GSH transferase to form the GSH conjugate DCVG and processing of the GSH conjugate by GGT and dipeptidase activities to generate the cystein conjugate $S-(1,2-$ dichlorovinyl) L. cystein (DCVC), Halled, C. J. and Cook, J. G. (1971). DCVC may also undergo sulfoxidation to form S-(1-chloro-2-(S-glutathionyl)-L-cystein sulfoxide (DCVC sulfoxide), which is a potent nephrotoxicant in rat kidney cells, Lash, L. H. et al. (1994). The present study confirms the previous study, Geoptar, A.R. et al. (1995)., that GGTP was increased due to TCE administration. Furthermore, the present study shows that the depletion of GSH enhances utilization of protein thereby increasing the urea level that is accompanied by an increased creatinine level suggested by, Mostafa, S. A. (998). Kombucha is a potent antioxidant demonstrated to reduce the damage induced by oxidative stress, Gomal, A. C. et al. (1949). ; Dalton, T.P. et al. (1999).; Gharib, O. A. (2007). and Anand, S. S. (2005). Results from the present study show that Kombucha ferment ameliorated TCE-induced hepato- renal damage, attributable to acetic acid which is capable of conjugating with toxins, solubilizing and eliminating them from the body, Dutton, G. (1980). Glucuronic acid, another important acid in Kombucha, facilitates the detoxification process in the body. UDP-glucuronic acid is formed in the liver of all animals and conjugates toxins for subsequent elimination Blanc, P. J. (1996). and Andlaur, W. et al. (2000)., reported that potential phytochemical toxins were detoxified in mammalian tissue by conjugation with glucuronic acid.

\section{CONCLUSION}

The present study indicates that Kombucha may repair damage caused by environmental pollutants such as TCE.

\section{Abbreviations}

DCVC: S-(1, 2-dichlorovinyl) L. cysteine; DCVC sulfoxide: S-[1-chloro-2(glutathionyl) vinyl]-L-cysteine sulfoxide); GGT: gamma glutamyl transpeptidase; GSH: glutathione; GSH 


\section{REFERENCES}

Agency for Toxic Substances and Disease Registry (ATSDR) (1997). Toxicological profile for trichloroethylene (TCE) Atlanta: US Department of Health and Human Services Public Health Service.

Anand, S. S. (2005). Protective effect of vitamin B6 in chromiuminduced oxidative stress in liver. J Appl Toxicol., 25:440-443.

Andlaur, W.; Kolb, J. and Furst, P.A. (2000). Novel efficient method to identify betaglucuroindase activity in rat small intestine. Parenter Enteral Nutr., 24(5):308-310.

Beutler, E.; Duran, O. and Kelly, B.M. (1963). Improved method of blood glutathione. J Lab Clin Med, 61(5):852-855.

Blanc, P. J. (1996). Characterization of the tea fungus metabolites. BiotechnolLett 18(2):139143.

Cojocel, C.; Beuter, W.; Muller, W. and Mayer, D. (1989). Lipid peroxidation: a possible mechanism of trichloroethylene induced nepherotoxicity. Toxicol, 55(1-2):131-141.

Dalton, T.P.; Shertzer, H.G. and Puga, A. (1999). Regulation of gene expression by reactive oxygen. Annu Rev Pharmacol Toxicol, 39:67-101.

Davidson, I. W. and Belilies, R.P. (1991). Consideration of the target organ toxicity of trichloroethylene in terms of metabolite toxicity and pharmacokinetics. Drug Metab Rev 23:493-599.

Dufresne, C. and Farnworth, E. (2000). Tea, kombucha health: a review. Food Res Int 336:409-421.

Dutton, G. (1980). Glucuronidation of Drugs and Other Compounds CRC Press.

Elcombe, C.R.; Rose, M.S. and Pratt, I.S. (1985). Biochemical, histological, and ultrastructural changes in rats and mouse liver following the administration of trichloroethylene: possible relevances to species differences in hepatocarcinogenicity. Toxicol Appl Pharmacol, 79(3):365-376.

Geng, Y.; Almqvist, M. and Hansson, G.K. (1994). DNA cloning and expression of inducible nitric oxide synthase from rat vascular smooth muscle cells. Biochim Biophys Acta, 1218:421.

Geoptar, A.R.; Commandeur, J.N.M.; Van Ommen B.; Van Bladeren, P. J. and Vermenten N.P.E. (1995). Metabolism and kinetics of trichloroethylene in relation to toxicity and carcinogenicity. Relevance of the mercapturic acid and pathway. Chem Res Tocicol $8(1): 3-21$.

Gharib, O. A. (2007). Does kombucha tea reduce the damage induced by radiation exposure? Egypt J Sci Applic, 20(1):141-157.

Gharib, O.A. and Fahim, T. H. (2007). Possible protective effect of kombucha tea ferment on carbon tetrachloride induced liver damage in irradiated rats. Egypt J Rad Sci Applic 21(1):97-115.

Gharib, O.A. and Gharib, M.A. (2008).Kombucha tea ameliorates trichloroethylene induced hepatic damages in rats via inhibition of oxidative stress and free radicals induction. Egypt J Sci Applic. 21(2):481-498.

Giordano, F.J. (2005). Oxygen, oxidative stress, hypoxia, and heart failure. J Clin Invest, 115(3):500-508.

Goel, S.K.; Rao, G.S.; Pandya, K.P. and Shanker, R. (1992). Trichloroethylene toxicity in mice: a biochemical, hematological and pathological assessment. Indian J Exp Biol, 30(5):402-6.

Gohn, A. (1986). ESR and Elementary Practical Applications New York: John Wiley;

Gomal, A. C.; Bardawill, C. J. and David, M.M. (1949). Colorimetric method for total protein determination. J Biol Chemi, 177:751pp.

Halled, C. J. and Cook, J. G. (1971). Reduced nicotinamide adenine dinucleotide- coupled reaction for emergency blood urea estimation. Clin Chim Acta, 35:33-40.

Halliwell, B. and Whiteman, M. (2004). Measuring reactive species and oxidative damage in vivo and in cell culture: how should you do it and what do the results mean? $\mathrm{Br} \mathrm{J}$ pharmacol, 142(2):231-255. 
Heckly, R. J. (1975). Biological applications of electron spin resonance. In Free Radicals in Dry Tissues Edited by: Swartz HM, Bolton JR, Borg DC. New York: Wiley Inter Science, pp.5.

Henery, R. J. (1974). From Principle and Techniques: Clinical chemistry $2^{\text {nd }}$ edition. New York: Harper \& Row; pp.525.

IFCC, (1980). Measurements of lactate dehydrogenase in serum. J Clin Chem Clin Biochem, 18:521.

Khan, S.; Priyamvada, S.; Khan, S.A.; Khan, W.; Farooq, N.; Khan, F. and Yusufi, A.N. (2009). Effect of trichloroethylene (TCE) toxicity on the enzymes of carbohydrate metabolism, brush border membrane and oxidative stress in kidney and other rat tissues. Food Chem Toxicol, 47(7):1562-1568.

Lash, L. H.; Qian, W.; Putt, D.A.; Hueni, S.E.; Elfarra, A.A.; Sicuri, A.R. and Parker, J.C. (2002). Renal toxicity of perchloroethylene and S-(1,2,2-trichlorovinyl) glutathione in rats and mice: sex- and speciesdependent differences. Toxicol Appl Pharmacol, 179(3):163-171.

Lash, L. H.; Tokarz, J.J. and Woods, E.B. (1994). Renal cell type specificity of cephalosporin- induced cytotoxicity in suspensions of isolated proximal tubular and distal tubular cells. Toxicology, 94:97-118.

Lash, L.H.; Qian, W.; Putt, D.A.; Hueni, S.E.; Elfarra AA, Krause RJ, Parker JC: Renal and hepatic toxicity of trichloroethylene and its glutathione- derived metabolites in rats and mice: sex-, species-, and tissue dependent differences. J Pharmacol Exp Therp 2001, 297(1):155-164.

Maltoni, C.; Lefemine, G.; Gotti, G. and Perrino, G. (1988). Long term carcinogenicity bioassays on trichloroethylene administered by inhalation to Sprague Dawley rats and Swiss and B6C3F1 mice. Ann N Y Acad Sci 534:216-342.

Mohammed, M. A. (2008). Effect of low dose of gamma radiation or silymarin treatment in reducing the toxicity induced by pollution with trichloro-ethylene solvent in rats. MSc thesis, faculty of science, Ain shams university.

Morales, G.B. and Sanchez H.H. (2003).Manufacture of a beverage from cheesewhey using "tea fungus" fermentation. Rev Latinoam Microbiol 45:5.

Mostafa, S. A. (998). Effect of allyl as glutathione depleting agent on carbohydrate metabolism in rats. Egypt J Ger Soc Zool, 26(A):13-34.

Nomiyama, K.; Nomiyama, H. and Arai, H. (1986). Revaluation of sub-chronic toxicity of trichloroethylene. Toxicol Lett, 31(1):225.

Pascual, E.C.; Goodman, B. A. and Yeretzian, C. (2002). Characterization of free radicals in soluble coffee by electron paramagnetic resonance spectroscopy. J Agri Food Chem, 50(21):6114-6122.

Sai Ram M.; Anju, B.P.T.; Dipti, P.; Kain, A.K.; Mongia, S.S.; Sharma, S.K.; Singh, B.; Singh, R.; Ilavazhagan, G.; Devendra Kumar and Selvamurthy, W. (2000). Effect of Kombucha tea on chromate (VI)-induced oxidative stress in albino rats. $J$ Ethnopharmacol 71(1-2):235-240.

Szasz, G. (1969). A kinetic photometric method for serum gamma glutamyl transpeptidase. Clin Chem, 15(2):124-136.

Wang, G.; Ansari, G.A. and Khan, M. F. (2007). Involvement of lipid peroxidation derived aldehyde- protein adducts in autoimmunity mediated by trichloroethylene. $J$ Toxicol Environm Health, 70(23):1977-1985.

Yoshioka, T.; Kawada, K.; Shimada, T. and Mori, M. (1979). Lipid peroxidation in maternal and cord blood and protective mechanism against activated-oxygen toxicity in the blood. Am J Obstet Gynecol, 135(3):372-376. 


\section{ARABIC SUMMARY}

\section{هل تقلل الكمبوشا من التأثيرات السمية الناتجة من بعض الملوثات البيئية علي الكبد و الكلي؟}

\section{علا علي غريب}

قسم البحوث الدوائية الإشعاعيةـ المركز القومي لَّحوث وريب تكنولوجيا الإشعاع - هيئة الطاقة الذرية

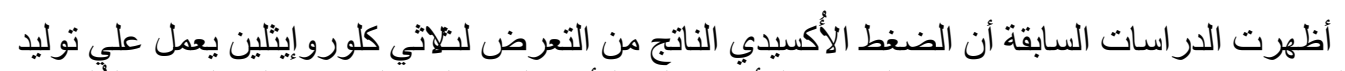

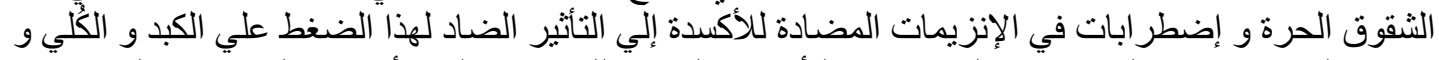

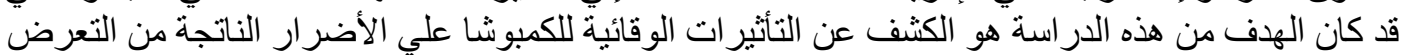

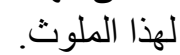

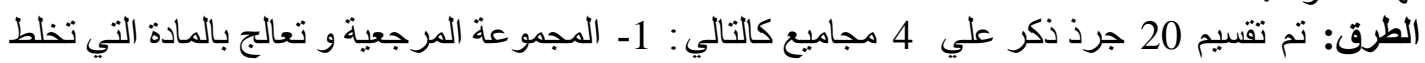

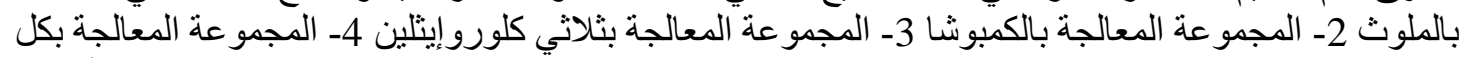

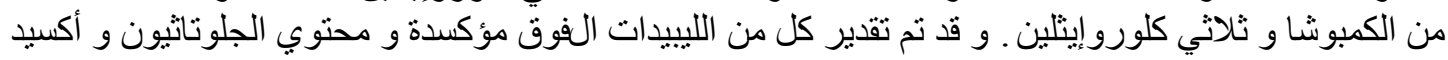

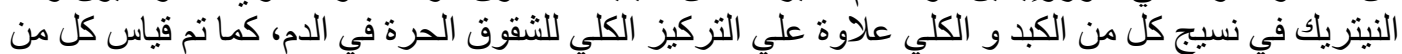

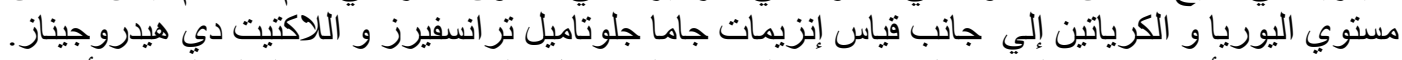

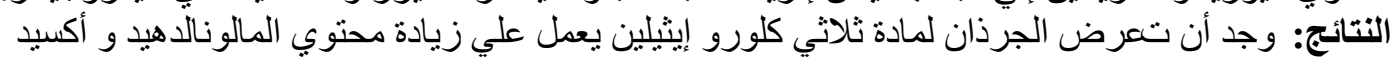

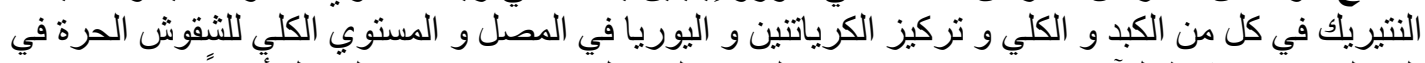

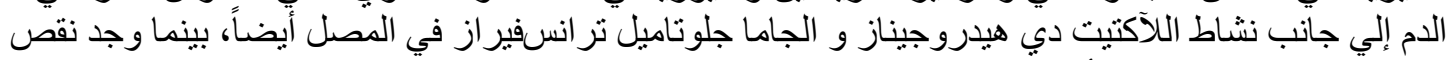

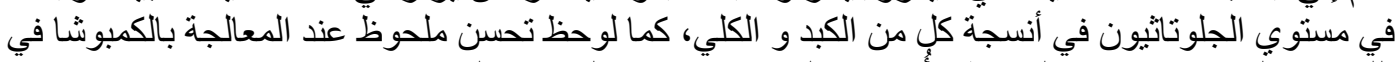

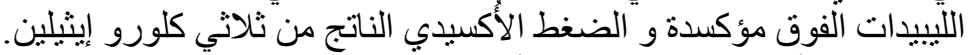

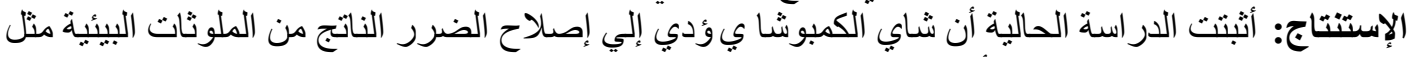

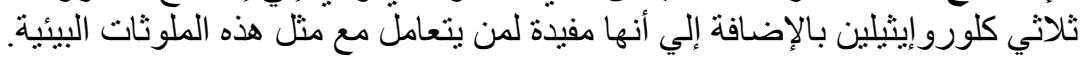

